\title{
ON SOME HADAMARD-TYPE INEQUALITIES FOR $h$-CONVEX FUNCTIONS
}

\author{
Mehmet ZeKi Sarikaya, AZIZ SAglam AND HÜsEYIN YILdirim
}

Abstract. In this paper, some inequalities Hadamard-type for $h$-convex functions are given. We also proved some Hadamard-type inequalities for products of two $h$-convex functions.

Mathematics subject classification (2000): 26D07, 26D15. function.

Key words and phrases: Hadamard's inequality, Convex function, $s$-convex function, $h$-convex

\section{REFERENCES}

[1] W. W. BRECKNER, Stetigkeitsaussagen für eine Klasse verallgemeinerter konvexer funktionen in topologischen linearen Raumen, Pupl. Inst. Math., 23 (1978), 13-20.

[2] W. W. BRECKNER, Continuity of generalized convex and generalized concave set-valued functions, Rev Anal. Numér. Thkor. Approx., 22 (1993), 39-51.

[3] S. S. Dragomir, J. PeCAric And L. E. Persson, Some inequalities of Hadamard type, Soochow J. Math., 21 (1995), 335-241.

[4] S. S. DRAGOMIR AND S. FITZPATRIK, The Hadamard's inequality for s-convex functions in the second sense, Demonstration Math., 32 (4) (1999), 687-696.

[5] E. K. GodunOVA AND V. I. LEVIN, Neravenstva dlja funkcii sirokogo klassa, soderzascego vypuklye, monotonnye i nekotorye drugie vidy funkii, Vycislitel. Mat. i. Fiz. Mezvuzov. Sb. Nauc. Trudov, MGPI, Moskva, 1985, pp. 138-142.

[6] H. HudziK And L. Maligranda, Some remarks on s-convex functions, Aequationes Math., 48 (1994), $100-111$.

[7] U. S. Kirmaci, M. K. Bakula, M. E. Ozdemir AND J. PeCaric, Hadamard-type inequalities for s-convex functions, Appl. Math. and Compt., 193 (2007), 26-35.

[8] D. S. Mitrinovic AND J. PeCARIC, Note on a class of functions of Godunova and Levin, C. R. Math. Rep. Acad. Sci. Can., 12 (1990), 33-36.

[9] D. S. Mitrinovic, J. PECARIC AND A. M. FINK, Classical and new inequalities in analysis, Kluwer Academic, Dordrecht, 1993.

[10] B. G. PACHPATTE, On some inequalities for convex functions, RGMIA Res. Rep. Coll., 6 (E), 2003.

[11] S. Varosanec, On $h$-convexity, J. Math. Anal. Appl., 326 (2007), 303-311. 